\title{
MICHEL FOUCAULT: THE LAST GREAT FRENCH HUMANIST
}

One hardly risks contradiction if one asserts that, of the French poststructuralists, it is Foucault who in recent years has been by far the dominant presence in the United States--at least since the de Man and Heidegger scandals substantially diminished the standing of Derrida some half a dozen years ago. Not only has deconstruction been displaced in large measure by New Historicism, but it is Foucault who has been the most significant French influence in cultural studies and multiculturalism, since the latter replaced postmodernity as the most significant and charged objects of debate in academic circles sometime in the mid to late $80 \mathrm{~s}$.

I should like to suggest here that the principal reason for this preponderance of Foucault's influence in the United States is that his work--more easily than that of the other French writers of his generation-enables one to continue working within a metaphysic of the subject and to prolong an intellectual project by no means inimical to liberal bourgeois humanism all the while appearing to call the latter fundamentally into question. (In this regard, the work of Foucault and the New Historicists performs a function in the United States similar to that fulfilled by Yale deconstruction in the 70 s and 80 s).

Given Foucault's own vituperations against the philosophy of the subject and against humanism, and the anathematization of Foucault by the apologists of the latter--from Sartre in the sixties to Ferry and Renaut in the eighties--my reading of Foucault may cause some initial surprise. This reading--Foucault as the last great French humanist (one more area in which Foucault has displaced Sartre, the former object of this once honourable and now egregious label)--this reading is, however, by no means entirely without precedent: in what is still probably the best-known study of Foucault in the English-speaking world, Hubert L. Dreyfus and Paul Rabinow develop a related criticism with regard to the notion of "archaeology" as developed in The Order of Things and, above all, in The Archaeology of Knowledge. These authors then proceed to exempt Foucault's subsequent works from their strictures. Now, there is very little of anything in Dreyfus' and Rabinow's book I am able to agree with; and as I suggest below, their criticisms are unfounded; I shall argue, however, that the later works are, in their own way, as "subjectivist"and humanist, in the Heideggerian and Derridean senses of these terms, as the earlier ones are for reasons altogether different from those advanced by Dreyfus and Rabinow. 
At the outset, I must recall at some length Foucault's own powerful account of the age of "man"--elaborated in the chapter of The Order of Things entitled "Man and his Doubles"--because it is in this account that we can begin to detect the limits of Foucault's attack on humanism. Foucault situates the onset of this age very precisely at the close of the eighteenth century, distinguishing it carefully from the humanism of the Renaissance or the rationalism of the seventeenth and eighteenth centuries which, "while they may well have granted a privileged status to human beings in the order of things, were nonetheless unable to

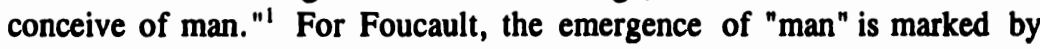
a radical shift in the reasons deemed to be at the basis of the finite, limited, character of human knowledge. For the seventeenth and eighteenth centuries, the positive determination of thought within finite forms--life, the body, language--entails a simple inadequacy of the latter to represent the infinite. For this period, it is this negative relationship to the infinite which is anterior to and founds empirical existence itself, and not just the limited knowledge one may develop of the latter. For the nineteenth century ("modern thought, " as Foucault puts it), on the other hand, it is history, work, language and so on which determine not just the limits of knowledge but its form and content; just as these limits of knowledge, in their turn, in a tormented circularity, make possible finite knowledge of life, work and language. "Man" emerges in the interstices of the following paradox: humanity is that which makes history, language and work possible; humanity is also, conversely, that which is made possible by the latter. For example, "man" is both more and less than the language which we speak: we alone would appear to have produced it, and yet it always precedes us, always prescribes and lays out our possibilities. Needless to say, not only does "man" emerge in this paradoxical space but so do what the French call the "scienceshumaines." The latter are defined by a constant attempt to overcome their own paradoxical emergence by rendering explicit, representing and exhausting the "unthought" conditions of their own existence by means of what Foucault calls an "analytic of finitude"--an account which will finally assimilate the radically Other of these conditions of existence into the Same: "... the whole of modern thought is imbued with the necessity of thinking the unthought--of reflecting the contents of the In-itself in the form of the For-itself, of

\footnotetext{
' Michel Foucault, The Order of Things (New York: Vintage Books, 1973) p.318, translation modified.
} 
ending man's alienation by reconciling him with his own essence. ${ }^{\text {"2 }}$ Like other poststructuralists, Foucault holds Marx and Hegel to be the foremost exemplars of this drive. Thus, in the Hegelian phenomenology, "... the totality of the empirical domain was taken back into the interior of a consciousness revealing itself to itself as spirit, in other words, as an empirical and a transcendental field simultaneously. ${ }^{3}$ Hitherto "unthought" conditions of possibility of knowledge are retrieved from outer darkness, brought into the light and represented in thought. That signification in language, for example, is always a function of the system in which it is imbricated is a permanent challenge to human attempts to represent the very systematicity of the system itself, a challenge to which the sciences humaines constantly try to rise. The circularity of this process (the representation is now itself a part of what was originally being explained) makes it easy to see why this drive entails the human sciences in an endless process of "demystifying themselves, ${ }^{n 4}$ an interminable pursuit of "the truth of all truth." bottomless pit of relativism: for example, in historicism (a mirror-image, for Foucault, of the analytic of finitude) "... the positive knowledge of man is limited by the historical positivity of the subject who knows, with the result that the moment of finitude is dissolved in the play of a relativity from which one cannot escape and which itself constitutes an absolute. ${ }^{n 6}$ With this observation, we already have some indication of the pointlessness of Dreyfus' and Rabinow's demand that Foucault's "archaeological discourse itself ... be accounted for and relativized. ${ }^{\text {7 }}$ Such a demand remains strictly within the épistemè of the human sciences. As do such

\footnotetext{
${ }^{2}$ Ibid., p.327.
}

${ }^{3}$ Ibid., p.248.

${ }^{4}$ Ibid., p.364.

'Ibid., p.341.

${ }^{6}$ Ibid., p. 372. Translation modified.

'Hubert L. Dreyfus and Paul Rabinow, Michel Foucault: Beyond Structuralism and Hermeneutics (Chicago: University of Chicago Press, 1983), p.99. 
related complaints that archaeology is an "ahistorical discipline. ${ }^{\text {"8 }}$

In the final chapter of The Order of Things, Foucault argues that "man" and his "doubles" began to be left behind when psychoanalysis--and then ethnology and finally linguistics--exceeded the bounds of representation--the mainstay of the older analytic of finitude--and made any anthropology or general theory of humankind otiose:

\begin{abstract}
Whereas all the human sciences advance towards the unconscious only with their back to it, waiting for it to unveil itself as fast as consciousness is analyzed, as it were backwards, psychoanalysis, on the other hand, points directly towards it with a deliberate purpose--not towards that which must be rendered gradually more explicit by the progressive illumination of the implicit, but towards what is there and yet is hidden .... psychoanalysis moves towards the moment--by definition inaccessible to any theoretical knowledge of man . . . at which the contents of consciousness articulate themselves, or rather stand gaping, upon man's finitude ... unlike the human sciences, which, even while turning towards the unconscious, always remain within the representable, psychoanalysis advances and leaps over representation, overflows it on the side of finitude. ..?
\end{abstract}

Thus, the Freudian "mythology" of Death, Desire and the Law "designate(s) the conditions of possibility of any knowledge about man." 10 Conditions of possibility which, for psychoanalysis, cannot, in contradistinction to the human sciences, be represented. Similarly, ethnology "like psychoanalysis questions not man himself, as he may appear in the human sciences, but the region which makes possible in general a knowledge of man." 11

Now, none of this is very felicitously expressed and these concluding pages to The Order of Things constitute little more than an adumbration of the precise nature of the shift to post-humanism that is alleged to have taken place. The shift is essentially announced rather than comprehensively and cogently demonstrated. Which is one reason why sympathetic commentators such as Dreyfus and Rabinow could get so much wrong and declare that Foucault's position does not significantly

\footnotetext{
'Ibid., p.97. I shall limit the delineation of my differences with these authors to these observations. I do not have the space, or the inclination, to engage at length with what I take to be a mostly misguided account of Foucault's work.

${ }^{9}$ Foucault, The Order of Things, p.374.

${ }^{10}$ Ibid., p.375.

"Ibid., p.378.
} 
differ from what preceded it; and why the most irritating misreading to which these pages gave rise--that "the end of man" meant not merely a decentering of humankind but its outright abolition (often also read as an abolition of the subject)--could enjoy any currency or credibility at all.

Foucault might have made his position clearer had he more explicitly pointed to the fact that what was new about his conception of linguistics, for example, was that it no longer considered its field to be composed exclusively of traces of human activity (without remainder). Comparison with the two volumes of Sartre's Critique of Dialectical Reason can be helpful here in clarifying the novelty of what Foucault is trying to convey: Sartre's book is a work which, with its powerfully conveyed sense of history as an enormous crushing process which conditions in minute detail the existential possibilities and very identities of people, is as antiindividualistic as anything Foucault ever wrote; nonetheless, in its account of the unmastered dimension of that history as no more than a practicoinert (the accumulated traces of human activity petrified in matter as an "anti-dialectic" which alienates human freedom), the Critique remains squarely within the tradition of what Heidegger called a "voluntarist" humanism. Similarly, as an attempt to redeem the ostensibly impersonal process of History as, in the final analysis, human praxis which can therefore be understood and mastered by human beings, Sartre's Critique falls under Foucault's definition of the human sciences as an attempt to bring within the purview of consciousness all the conditions of possibility of the latter; and as such, of course, a project of this kind remains within a philosophy of subject and object. It will be recalled, from a passage quoted earlier, that this was precisely Foucault's objection to historicism, or the investigation of the historicity or "relativity" of the human sciences (an undertaking with which his own work is so often erroneously confused):

Historicism is a means of validating for itself the perpetual critical relation at play between History and the human sciences. But it establishes it solely at the level of the positivities: the positive Inowledge of man is limited by the historical positivity of the knowing subject, so that the moment of finitude is dissolved in the play of a relativity from which it cannot escape, and which itself has value as an absolute. To be finite, then, would simply be to be trapped in the laws of a perspective which, while allowing a certain apprehension--of the type of perception or understanding--prevents it from ever being universal and definitive intellection. All knowledge is rooted in a life, a society, and a language that have a history. . . 12

\footnotetext{
${ }^{12}$ lbid., pp.372-373. Emphasis added.
} 
The crucial qualification here is, "But it establishes it at the sole level of the positivities ...,"i.e. at the sole level of the subject ("man") and object (also "man") referred to in the rest of the sentence. How crucial this clause is will become apparent shortly.

In the meantime, what Foucault has in mind as an alternative locus for this "critical relation between History and the human sciences" becomes clearer in the subsequent Archaeology of Knowledge in which the notion of archaeology is itself finally defined as "The never completed, never wholly achieved uncovering of the archive [which] forms the general horizon to which the description of discursive formations, the analysis of positivities, the mapping of the enunciative field belong. ${ }^{13}$ This sounds anodine enough, especially if one makes the mistake of believing that what Foucault is referring to by the archive or discursive formations is of the domain of language. Misreadings in this area have been understandable given Foucault's own somewhat intermittently clear vision of the strange new realm he had stumbled into. Thus, readers are easily misled by definitions of the archive like "It is the general system of the formation and transformation of statements. ${ }^{14}$ Here, on the other hand, is a passage which is rather more helpful:

... from the kind of analysis that I have undertaken, words are as deliberately absent as things themselves; any description of a vocabulary is as lacking as any reference to the living plenitude of experience. We shall not return to the state anterior to discourse--in which nothing has yet been said, and in which things are only just beginning to emerge out of the grey light; and we shall not pass beyond discourse in order to rediscover the forms that it has created and left behind it; we shall remain, or try to remain, at the level of discourse itself .... I would like to show that "discourses, "in the form in which they can be heard or read, as they can be read in their form as texts, are not, as one might expect, a mere intersection of things and words: an obscure web of things, and a manifest, visible, coloured chain of words; I would like to show that discourse is not a slender surface of contact, or confrontation, between a reality and a language (langue), the intrication of a lexicon and an experience; I would like to show with precise examples that in analysing discourses themselves, one sees the loosening of the embrace, apparently so tight, of words and things, and the emergence of a group of rules proper to discursive practice. These rules define not the dumb existence of a reality, nor the canonical use of a vocabulary, but the ordering of objects. . .. A task that consists of not--of no longer--treating discourses as groups of signs

\footnotetext{
${ }^{13}$ Michel Foucault, The Archaeology of Knowledge, trans. A. M. Sheridan Smith (New York: Pantheon, 1972), p.131.

"It Ibid., p.130.
} 
(signifying elements referring to contents or representations) but as practices that systematically form the objects of which they speak. Of course, discourses are composed of signs; but what they do is more than use these signs to designate things. It is this more that renders them irreducible to language (langue) and to speech. It is this "more" that we must reveal and describe.

It is in this kind of passage--more frequently found in The Archaeology of Knowledge than elsewhere in his works--that Foucault expresses the position fundamental to poststructuralism as a whole, the ultimate consequences of which he himself--I shall argue here shortly--never fully grasped or committed himself to: namely, that while it is doubtless possible to distinguish between "words" and "things, "together they form a seamless web or "general text" (Derrida) in which--yes--that which is no longer quite of the order of "words" forms "objects" like madness and homosexuality (Foucault), but in which "things" and "objects" are no less apt to constitute a language, "code" or "articulated order" all on their own (Baudrillard). Poststructuralism's transformation of how, henceforth, we must think of these notions--discourse, objects etc.--is, even today, still not fully grasped; which is why, more than twenty years after these works first appeared, one still finds denunciations of poststructuralism as an idealism of the text (or discourse), as an epistemological nihilism and so on. In the poststructuralist corpus, The Archaeology of Knowledge is unusually explicit and helpful on this subject. For example, among the multifarious elements which make the emergence of the objects of the discourse of psychopathology possible in the nineteenth century, Foucault distinguishes the following: the family, the work environment, the religious community (which all define madness by exclusion); the medical profession, the judiciary and the religious authorities; the relationships between these bodies and the different norms they have adopted; the relationship between therapeutic confinement within hospitals and confinement within the prison system. And so on and so forth (the enumeration and description of these elements and their relations runs to several pages).$^{16}$ Foucault concludes, notoriously, that the object in question (madness, for example) does not already exist before it is "discovered" by the discourse of psychopathology (hence the accusation of idealism ); rather, it comes into existence "... under the positive conditions of a complex bundle of relations. .. These relations are established between institutions,

\footnotetext{
is Ibid., pp.48-49.

${ }^{16}$ Ibid., p. $40 \mathrm{ff}$.
} 
economic and social processes, behavioural patterns, systems of norms, techniques, types of classification, modes of characterization. ${ }^{17}$ Foucault then adds the following crucial qualification: "... these relations are not present in the object; it is not they that are deployed when the object is being analyzed; they do not indicate ... the immanent rationality, that ideal nervure that reappears totally or in part when one conceives of the object in the truth of its concept. They do not define its internal constitution, but what enables it to appear, to juxtapose itself with other objects . . . in short, to be placed in a field of exteriority. ${ }^{n 18}$ A page earlier, Foucault asserts that it is these relations, "at work in psychiatric discourse, which have enabled the formation of the entire panoply of this discourse's objects." ${ }^{19}$ These relations, while they may well be "at work" (à l'oeuvre) in discourse, are nevertheless not internal to discourse: they do not link concepts and words, nor do they establish "a rhetorical or deductive architecture" between sentences and propositions. ${ }^{20}$ Nor, however, are they "outside" of discourse; for this would presuppose that objects and discourse are formed independently of each other, or that they occupy different realms of existence. Rather, these relationships determine the network of relations which discourse must establish if it is to be able to discuss, analyse and classify certain objects. These relations, therefore, are neither a function of languagenor a function of context, but a function of discourse itself as practice. ${ }^{21}$

Very well.

The question which needs to be addressed here, however, is whether all of this truly constitutes a decisive break with humanism. Foucault, his disciples, and his many critics, clearly all believe so; and, indeed, on first reflection the belief seems to be justified; especially given the following passage which can, I maintain, be applied to all that has been outlined above, even though, strictly speaking, it describes the conditions for the "rules for the formation of concepts":

\footnotetext{
${ }^{17}$ Ibid., p. 45.

"Ibid..

${ }^{19}$ Ibid.. p.44, translation modified.

${ }^{20}$ Ibid., p.46, translation modified.

${ }^{21}$ Ibid.
} 
... the rules governing the formation of concepts, however generalized the concepts may be, are not the result, laid down in history and deposited in the depth of collective customs, of operations carried out by individuals. . . .

Like so much of The Archaeology of Knowledge, this is clearly directed at Sartre's Critique of Dialectical Reason and the Sartrean notion, discussed earlier, of a "practico-inert": that which constrains or "alienates" individual freedom ("situation" or context, cultural structures etc.) is no more than the accumulated and congealed deposit of previous human activity which has acquired a momentum, or inertia, all of its own. ${ }^{23}$

Foucault continues the passage quoted immediately above in the same vein, making explicit the degree to which these remarks on the subject of the formation of concepts are, as I have suggested, part of a broader articulation including the formation of objects and so on:

... they [the rules governing the formation of concepts] do not constitute the bare schema of an entire labour conducted in obscurity, in the course of which concepts would be made to emerge through illusions, prejudices, errors, and traditions. The preconceptual field allows the emergence of the discursive regularities and constraints that have made possible the heterogeneous multiplicity of concepts, and, beyond these the profusion of the themes, beliefs, and representations with which one usually deals when one is writing the history of ideas.

In order to analyze the rules for the formation of objects, one must neither, as we have seen, embody them in things, nor relate them to the domain of words; in order to analyze the formation of enunciative types, one must relate them neither to the knowing subject, nor to a psychological individuality. Similarly, to analyze the formation of concepts, one must relate them neither to the horizon of ideality, nor to the empirical progress of ideas. ${ }^{24}$

All of this certainly tempts one to conclude that Foucault's position is beyond humanism. This conclusion appears irresistible after the following passage in which Foucault declares that the subject of a statement is never the same as the author of any particular contingent verbal formulation, but

\footnotetext{
${ }^{22}$ Ibid., p.63.
}

${ }^{23}$ The Introduction to The Archaeology of Knowledge, in particular, is full of implicit references to Sartre, especially pp.19-20of the French edition (Gallimard, 1969)(the English translation, strangely, omits a footnote which contains a very direct allusion to Sartre's attack on Foucault which appeared in l'Arc: "Jean-Paul Sartre répond," Interview with B. Pingaud, l'Arc, 30 [1966], 87-96).

${ }^{24}$ Foucault, The Archaeology of Knowledge, p.63 (translation modified). 
rather a vacant space which makes the latter a possibility for, in principle, any number of authors:

\begin{abstract}
So the subject of the statement [le sujet de l'enonce] should not be regarded as identical with the author of the formulation--either in substance, or in function. It is not in fact the cause, origin, or starting-point of the phenomenon of the written or spoken articulation of a sentence; nor is it that meaningful intention which, silently keeping ahead of words, orders them like the visible body of its intuition; it is not the constant, motionless, identical-to-itself home of a series of operations that are manifested, in tum, through the statements. It is a determinate, empty place that may in fact be filled by different individuals. ${ }^{29}$
\end{abstract}

At the very least, this unequivocally goes beyond individualism. (In passing, one should perhaps emphasize the extent to which this kind of passage invalidates any reading of Foucault which suggests that it was ever his intention to deny the existence of subjectivity [in the colloquial sense of the term] or to dissolve it in discourse. The intention was always--as this passage abundantly demonstrates--to show what makes forms of subjectivity possible). But, of course, in this regard alone --i.e. going beyond individualism--there is nothing novel to anything Foucault is doing here, insofar as both the Hegelian dialectic and Marxism had already made this move. Whether any of the above goes beyond humanism--not at all the same thing as individualism--whether, in other words, it advances significantly beyond the Hegelian and Marxist dialectics is altogether another question.

In order to answer this question, we must make a detour through Heidegger and Derrida's dismantling of the Hegelian subject. (Heidegger is the principal source of inspiration for the assault launched against humanism and the philosophy of the subject in France in the sixities. As we shall see, Foucault, unlike Derrida, either never fully understood Heidegger's position, or else chose not to accept its ultimate implications). Readers of Hegel's Science of Logic will recall that identity and difference emerge as the outcome of a meditation upon pure being: the realization

${ }^{25}$ Ibid., p.95. I have substantially modified Sheridan Smith's translation. He has betrayed Foucault's intention with the conspicuously unfortunate translation of the third sentence in the French original (the second sentence in the English translation). Thus, Sheridan Smith translates "Il n'est pas en effet cause, origine ... " by "He is not in fact .. . "; whereas the third person singular pronoun Il refers back to le sujet de l'enoncẹ (the subject of the statement) which Foucault is expressly characterizing as not human. The correct translation should therefore be "It." Sheridan Smith's unwitting slip is a helpful reminder of the tenacity of the humanist delusion: Sheridan Smith simply cannot conceive that the subject of a statement can be anything but human. 
that pure undifferentiated being ("the indeterminate immediate") is the equivalent of pure nothingness, and that, translated into Aristotelian logic, this equivalence reveals itself as the tautologous "verbiage" of $A=A$ in which "nothing" is said, this realization is the first moment of "becoming" (being turns into nothing) and it is what enables the first pair of identities and the first difference to appear: namely the difference between being and nothingness. ${ }^{26}$ Now, this manner of proceeding is precisely what Heidegger had denounced as early as his great Nietzsche study as the nec plus ultra of a tendency which began with Descartes: the process whereby "... man becomes the measure and the center of beings. "27 For, clearly, in the Hegelian system what we have is a mind--Absolute Spirit, in the final analysis--engaged in meditations upon its own thought processes. And while Absolute Spirit may have been more than "man" to Hegel, that it is an hypostasis of merely human cogitation is perfectly plain to us. Heidegger described the Hegelian system as the acme of subjectivism and onto-theology, because in it the ground of all beings, Absolute Spirit, is construed as an unconditioned subjectivity. In Heideggerian terms, Being is turned into a being--just another being--but one which is magically free of the welter of determinations, negations and difference which condition all other entities. In contrast to the Hegelian system, Heideggerian Being (which for reasons of space I cannot discuss here) and Derridean differance do not locate the determination of the identity of entities in subject-centred differentiation or negation; in the case of differance, identity is endlessly deferred throughout the "whole." What this means--in terms of the now impossible language of ontology--is that the meaning or identity of anything is intricated with everything else in the universe (I shall explain this assertion below). Those who are surprised by the simultaneous mention of Derrida's name and "ontological"considerations of this kind--in other words, those who still, at this late date, subscribe to the view that this work constitutes an idealism of the text (in the colloquial sense of the latter term)--such readers are referred to the distinction, made as early as the Grammatology, between text in the colloquial sense and the "general text" or "play of the world."

The point is worth emphasizing because this erroneous linguistic turn given to the Derridean text has also been attributed (by enemies and

${ }^{26}$ Georg Wilhelm Friedrich Hegel, Science of Logic, trans. A.V. Miller (Atlantic Highlands: Humanities Press International, 1989), pp.82-83 and p.411ff, especially p.415.

\footnotetext{
${ }^{27}$ Martin Heidegger, Nietzsche, trans. David Farrell Krell et al. (New York: Harper \& Row, 1982), IV, 28.
} 
enthusiasts alike) to Foucault's notion of discourse which, as we have seen earlier, is explicitly described as beyond both words and things as these have been differentiated hitherto. Thus, the English translation of the title of Foucault's inaugural address at the College de France, l'Ordre du discours, reads as The Discourse on Language. ${ }^{28}$

It is important to be quite clear as to what distinguishes Derrida's position so radically from earlier ones. As a point of comparison, we can refer to the most powerful and sophisticated account of identity and difference to have preceded Derridean differrance: the Marxist explanation of commodity fetichism. I evoke Marxism here because the difficulties it got into in the 1960s are, of course, central to an understanding of the development of poststructuralism and they will make it easier to grasp what is at stake in the confrontation of Foucault with Derrida. It matters little here how closely we cleave to Marx's own account of commodity fetichism, or whether we adopt the language of any one of the more recent versions of the Marxist tradition like Althusser's or that of the Hegelian Marxists. If we follow the Hegelian-Marxist tradition, then we will tend to explain the exchange-value of a particular commodity (and hence its glamour or lack thereof, its social meaning or identity) with special emphasis on the totality of social relations (socially necessary labour time, an entire dialectic of social contradictions etc.) which give rise to a particular value. If, on the other hand, we adopt the theoretical language of Althusser and his collaborators, then we will tend to subordinate such contradictions to a mode of production as structure. In neither case, is it a matter of reducing strictly singular elements of a complex whole to mere expressions of a totality, the differentiated parts of which would all contain the totality as an essence, or concept (in the manner of Hegel). The limitation of Marxism, in this regard, is not that it presents a danger of homogenization or reductionism (as in "economism"), that bogeyman of liberal bourgeois thought. Hegelian Marxism, for example, has shown itself to be particularly adept--most spectacularly in the last work of Sartre, the astonishing (and disgracefully underread) biographical study of Flaubert-not just at avoiding this pitfall but at demonstrating with extraordinary subtlety the irreducible singularity of an individual existential adventure within a larger narrative of class-struggle and so on.

No, our quivering, precious individual sensibilities-our "differences," as they say (in unison)--are safe. The limitation, which is common to Marxism and the work of Foucault, lies elsewhere. It becomes

${ }^{28}$ "The Discourse on Language," in The Archaeology of Knowledge. 
evident as a direct result of the Heideggerian dismantling of the philosophy of the subject and the appearance on the philosophical scene of différance; and it resides in the fact that the latter both entail the following consequence: when attempting to explain the emergence of any phenomenon in the social field, any cultural artefact or the "formation of objects, "the limiting of the pertinent relations, structures, determinations (whatever you choose to call them) held to be relevant to this emergence can no longer, henceforth, be restricted to the merely human domain. By contrast, Foucault, as I shall demonstrate in a moment, appearances to the contrary notwithstanding, does exactly this.

In the meantime, however, it is necessary to clarify the shift introduced by differance announced directly above. The truly disconcerting import of differance lies in its disqualification of any ground or sub-jectum ("that which underlies") as the Being of beings. (One should add that the assault on the philosophy of the subject--as Heidegger's emphasis on the etymology of the word suggests--was not only aimed at human subjects; if anything other than a human subject seems strange or inconceivable, then this is only a function of a our persistant humanism.) This disqualification of a ground is the consequence of taking seriously the idea that there can be no entity--Hegel's Absolute Spirit, for example, or God--which is itself unconditioned, and therefore able to perform the function as sole ground of other entities. This is the meaning of the notorious statement to the effect that "there is no outside to the text"--the text in the sense of what Derrida calls the "general text" or the "play of the world." Furthermore, if all entities are conditioned, they must all be conditioned by the entirety of the universe, in the sense that nothing in the universe can be what it is without the simultaneous existence of everything else. This is, of course, an elementary truth of our modern natural science; but its consequences have only been felt in the social sciences for a relatively short time. For example, this idea is the (mostly unacknowledged) underpinning of the repudiation, in recent years, of all forms of "determination in the last instance." The real reason there can be no such thing should not be that it offends our liberal bourgeois sensibilities (which is generally the secret motivation behind ostensible objections to "reductionism, " "totalitarianism" and so on) but that a "determination in the last instance" could only qualify as such if it were, itself, unconditioned by anything else. Failing this, whatever conditions the determination in the last instance becomes the new form of the latter, and so on ad infinitum.

It is necessary to point out that this difficulty is not obviated if, in contrast to a more traditional kind of Marxism with its emphasis on the narrowly economic, one adopts the significant improvement of Althusser 
and makes of the entire mode of production a "complex whole," an "articulated structure with a dominant" ("[une] structure articulée a dominante"). ${ }^{29}$ (The principal or dominant contradiction here being that between forces of production and relations of production. $)^{30}$ In this view of matters, the "economic" domain figures as merely one element (albeit a dominant one) of a whole which is constituted by the myriad relations among all the levels of the social formation: "... each contradiction, each essential articulation of the structure, and the general relationship among the articulations in the structure with a dominant, constitute so many conditions of existence of the complex whole itself." . the secondary contradictions are essential to the very existence of the principal contradiction. . they constitute in a real way the condition of existence of it, just as the principal contradiction constitutes their condition of existence. ${ }^{132}$ The problem with this formulation is that, by conceding that the dominant contradiction owes its existence to all the others, the way is opened to one's wondering as to how that one contradiction can continue to be dominant, or even how it could ever have been so in the first place. One is all too swiftly led, in other words, to asking--with Baudrillard, for example--whether the primacy given to political economy in the interrogation of social reality is not itself the final ruse of a form of social domination which depends on this image of itself (as subordinated to the economic) in order to function successfully. ${ }^{33}$ (This much said, let me hasten to add that my reiteration of the problematization of Marxism in the sixties and seventies in France should not be taken as a call for a summary abandonment of Marxism. Marxism [like the work of Foucault, as we shall see shortly] must be retained; but it needs to be hooked up to a transhuman order of things. In this regard, Derrida's recent warning against a facile dismissal of Marxism in our present circumstances is

\footnotetext{
${ }^{29}$ Louis Althusser, Pour Marx (Paris: Maspero, 1965), p.210. I prefer this translation of structure dominante to the, at best, misleading, "structure in dominance" so often used.

${ }^{30}$ Ibid., p.214.

${ }^{31}$ Ibid., p.210.

32 Ibid., p.211.

${ }^{33}$ Jean Baudrillard, Le miroir de la production (Paris: Casterman, 1973).
} 
timely). ${ }^{34}$

I have embarked on this discussion of Marxism because it illuminates the case of Foucault, to which we can at last return. The difficulties presented by Althusser's "structure with a dominant" closely parallel what I shall now demonstrate to be Foucault's residual humanism. It will be recalled that we were trying to establish how thorough-going Foucault's attempt to move beyond humanism really was. We had established that, for Foucault, in order to analyze the rules for the formation of objects, we could not embody them in words or things; nor could we relate the formation of enunciative types or concepts to knowing subjects or the history of ideas. Rather, an object (madness, for example) comes into existence "... under the positive conditions of a complex bundle of relations ... between institutions, economic and social processes, behavioural patterns, systems of norms, techniques, types of classification .... " ${ }^{35}$ This emphasis everywhere in The Archaeology of Knowledge on relations, on the "dispersion" of statements and "their simultaneity which is not unifiable, ${ }^{n 6}$ undoubtedly constitutes a move beyond a totalizing humanist subject. This move, however, is incomplete because the relations in question are--as the above passages make plain-always exclusively at work within an ambit which is human or, more precisely, social. While it may well be the case that the decisive relations which permit the existence of a particular object are neither present to a mind--collective or individual--nor the products of humanity (even of a humanity which does not know what it is doing, as in Marxist alienation)-while all this may well be the case, the entities and practices among which these relations are established by Foucault are nonetheless always exclusively social. (This is equally true of Althusser, with the additional problems entailed by the "dominant" in his structure--i.e. like Foucault's, Althusser's liquidation of humanism is incomplete). This is in flat contradiction with the following avowal of intent:

It is a matter of deploying a dispersion that can never be reduced to a single system of differences, a scattering that is not related to absolute axes of reference; it is a matter of operating a decentering that leaves no privilege to any

\footnotetext{
34 Jacques Derrida, Spectres de Marx (Paris: Galilée, 1993).

${ }^{33}$ Foucault, The Archaeology of Knowledge, p. 45.

${ }^{36}$ Ibid., p.127.
} 
center. ${ }^{37}$

It is as if even Foucault's post-humanism can only operate within the reassuring perimeter of a humanist notion: namely, that (thoroughly bourgeois) "civilsociety" which has been the unquestioned paradigmatic boundary for human self-understanding since at least Vico's The New Science of 1725, probably the best-known early expression of the exemplary humanist view that we are the authors of our own "world of nations or civil world." 38

One might add--lest I am accused of concentrating unfairly on Foucault's early work--that, if anything, the tendency I have tried to identify here--a residually humanist concentration on civil society as a privileged center of differential relations--becomes more overt towards the end of Foucault's oeuvre. This is one reason I have chosen to devote most space to the fiercely and explicity anti-humanist early works: it is more difficult to make my case with reference to them; and it seems to me that once one has made the case for the early works one scarcely needs to spell out the extent to which it can be done for the later ones. I have no intention, however, of being critical of the much-touted, and frequently misunderstood, "return of the subject" in the final works. The correct response on this score was succinctly made by Deleuze:

It is idiotic to say that Foucault discovers or reintroduces a hidden subject after having denied it. There is no subject, but a production of subjectivity: subjectivity is to be produced, at the right moment, because there is now a subject. ${ }^{39}$

Foucault did not "return" to the subject for the simple reason that he had never abandoned it in the first place. As we have seen above, in the early works he had been concerned to articulate the matrices of relations which

${ }^{37}$ Ibid., p.205 (translation modified and emphasis added).

${ }^{36}$ It is true, of course, that Vico, unlike Foucault, does locate the principles of civil society within "our own human mind": "the world of civil society has certainly been made by men, and that its principles are therefore to be found within the modifications of our own human mind. Whoever reflects on this cannot but marvel that the philosophers should have bent all their energies to the study of the world of nature, which, since God made it, $\mathrm{He}$ alone knows; and that they should have neglected the study of the world of nations or civil world, which, since men had made it, men could hope to know" (Giambattista Vico, The New Science, trans. T. Bergin and M. Fisch [Ithaca: Cornell University Press, 1948], p.331).

${ }^{39}$ Gilles Deleuze, Pourparlers (Paris: Minuit, 1990), p.154. 
made a place in which subjectivity could emerge possible. There is strictly no contradiction between an excercise of this kind and the accounts of "practices of the self" which mark the final period of Foucault's writings. This is a good point at which to make clear that it has not been my intention to dismiss Foucault's accounts of madness, sexuality and so on on the grounds of their egregious humanism. The fact that these accounts-accounts of bundles of relations which operate their effects independently of human subjects--are nonetheless held to act among entities within a strictly human domain does not necessarily invalidate any of them. Who, after all, could not be swayed by these magisterial studies? It is important to stress, too, that to complain about humanism is by no means to evacuate humanity from one's theoretical discourse. People do constitute themselves through practices of the self. And societies do regulate themselves (today) and individualize and subject (assujetir) people through the agency of the State (among other things). I take these to be facts--as solid and provisional as any fact supplied by the natural sciences. And there can be no doubt that Foucault has been instrumental as few have been in directing us down a path, beyond humanism, which I should like to see us pursue further. What I would suggest at this point is that one can nonetheless imagine intricating Foucault's analyses within a much larger transhuman framework which might well radically alter our understanding of them. At the very least, it would no longer seem admissible today--given the ecological crisis and what it has taught us about the inseparability of everything about ourselves, from our bodies to our social institutions, from the biosphere--to continue to work with a notion of "society, "or humanity, as a closed system. Despite Foucault's considerable debts to Heidegger, it would seem that he never fully assimilated--and our contemporary practitioners of cultural studies have most certainly yet to do so--Heidegger's warnings about the modern "anthropological" notion of "culture" and "world-view"as "the transition of metaphysics into its final configuration. ${ }^{400}$

I anticipate that it may be argued, at this point, that I have exaggerated the extent to which our humanist tradition has drawn a boundary around civil society as the paradigmatic object of human selfunderstanding. It is true that, within this tradition, there have been plenty of endeavours which have ostensibly cut across, or have been hostile to, humanism: investigations of human biology, neurophysiology or genetics, for example. Even these approaches, however--by virtue of their dominant

\footnotetext{
${ }^{40}$ Martin Heidegger, Nietzsche, IV, p.149; see also pp.17 and 86.
} 
tendency to represent the soma (or, more broadly, "nature") either as an unrelated, contingent, support or point of departure from which the "social"then takes its independent course, or as a rival locus of theoretical explanation for the social (as in genetic reductionism)--even these approaches have tended to reinforce, rather than significantly contest, a long habit of interpreting (in practice, if not in principle) the social as a separate, and not just distinct, domain from everything else which makes us what we are. The unreduced enclaves of Foucault's secret allegiances to this tradition--his privileging one "center," namely civil society--seem increasingly quaint in the context of recent work in a wide array of different fields which is complicating and challenging the divides we have operated between culture and nature, humanity, its machines and animals, and the environment. I am thinking of writing by Bruno Latour (in philosophy of science), Michel Serres (on the "natural contract"), Fellix Guattari (on the "three ecologies"), Edgar Morin and Anne Brigitte Kern ("la terre-patrie"), Donna Haraway (on simians, cyborgs and "the reinvention of nature"), or Ravi Batra (on economic cycles as bound up with biological ones), to name only some of the most prominent figures in this new field. This work suggests that we may have to drop altogether the notion of culture, as currently understood (i.e. as a residue of humanism/anthropomorphism [Heidegger/Derrida and others]), and ultimately conceive of the objects of cultural studies, for example, along the lines of cosmic events.

Now, clearly this will have to be done without relapsing into explanations based on teleologies or biological/natural conati, for these would constitute a continuation of the metaphysic of the subject (in the strict sense of the term, as employed by Heidegger and Derrida). (In other words, "nature, "for example, would become the new sub-jectum or ground.) To those--both opponents and promoters of poststructuralism-who have chosen, mistakenly, to see in the latter a "nihilistic" assault on truth, irresponsible relativism, a will to fragmentation and a resolute hostility to an invocation of any notion whatsoever of the whole or "totality, "it may come as a surprise to learn that it is the notorious notion of différance which has made possible, for the first time in our tradition, a discourse of the whole which is no longer burdened by that freight of phallogocentrism, onto-theology and so on from which we would like to free ourselves. It is often forgotten that the hostility of Heidegger and Derrida to the notion of totality was only directed at the version of the latter as an organization of entities around a project or telos. If, by contrast, the identities of entities are not determined by a center which grounds them in a system of differentiation and negation, then they are 
endlessly deferred throughout an infinite "whole" which itself cannot be thought or made the object of a concept. As stated earlier, in the now impossible language of ontology, this means that the identity or meaning of anything must be intricated with everything else in the infinite multiplicity of the universe. The latter, however, cannot be said to exist as a totality in the manner that term has often implied: i.e. it cannot be a matter of already constituted entities interactingwithin a system (as in many accounts of the modernist artwork, for example). This for the reason that, if each entity achieves its identity by means of its deferral through everything else, then its own contribution to the meaning and identity of everything else must already come to it from the whole "before" it can begin to make such a contribution. It must, in other words, always already be divided from itself in its own being. The very inadequacy of this language of ontology, which I have mobilized in the immediately preceding sentences, suggests the extent to which Being/différance is an unfathomable enigma to thought. In its very inadequacy, however, this language should convey the extent to which things no longer are in any traditional, substantial way. Which explains why poststructuralism has operated under the aegis of the feminine principle (by which I do not mean anything biologically female). (Irigaray, better than anyone else, has demonstrated how philosophy had generally worked with a notion of the entity which was on the model of the phallus as indivisible thing). Clearly, henceforth, we are constrained to think of all entities, including ourselves, as simultaneously nothing and everything. This vast Embrace of Being, if you will, should make apparent why, far from entailing an abdication from ethical and political choice (as has sometimes been claimed), différance imposes instead an enormously expanded sense of responsibility for all entities to the precise extent that we are all inextricably bound up with all of them. Furthermore, bearing in mind the exemplary analyses of Irigaray, we must conclude that Foucault's residual humanism, as defined here--and that of the majority of the current practitioners of cultural studies--elevates humanity to the same status as the Phallus in psychoanalysis: an unconditioned (except, in the case of humanity, by itself) sub-jectum or ground of the system of difference.

It is in the light of these novel circumstances that the vestigial humanism of Foucault, and his many theoretical progeny in New Historicism and cultural studies, needs to be reconsidered. More than most, Foucault himself has taught how inseparable power and knowledge always are. While his work has unquestionably been of major importance to those of us who seek to liberate ourselves from the toils of the subjection (assujetissement) and individualization at work in the modern 
world, the fact that Foucault, New Historicism and cultural studies have failed to call into question the terrain of social conflict chosen by the social engineers, policy wonks and other disciplinary minions of the liberal bourgeois social order--a humanist notion of "society"--suggests that the war may have been lost in advance.

Rice University

PHILIP R. WOOD 